\title{
Improving Carrot Yield and Quality through the Use of Bio-Slurry Manure
}

\author{
Agnes Jeptoo ${ }^{1}$, Joseph N. Aguyoh ${ }^{1} \&$ Mwanarusi Saidi ${ }^{1}$ \\ ${ }^{1}$ Department of Crops, Horticulture and Soils, Egerton University, Egerton, Kenya \\ Correspondence: Agnes Jeptoo, Department of Crops, Horticulture and Soils, Egerton University, Egerton, \\ Kenya. Tel: 254-725-087-719. E-mail: agijep@gmail.com
}

Received: September 10, 2012 Accepted: October 23, 2012 Online Published: November 25, 2012

doi:10.5539/sar.v2n1p164

URL: http://dx.doi.org/10.5539/sar.v2n1p164

\begin{abstract}
Continuous cultivation of farms has led to decline in soil fertility due to constant removal of nutrients leading to reduction of carrot (Daucus carota L.) yields. A field study was carried out at Egerton University, Horticulture Research and Teaching field in two seasons (October 2010 to January 2011 and February to May 2011) with the aim of investigating the effects of decomposed cattle bio-slurry manure on carrot growth and performance. The experimental design was a Randomized Complete Block Design (RCBD) with 3 replications. Treatments comprised four levels $(0,2.6,5.2$ and $7.8 \mathrm{t} / \mathrm{ha})$ of decomposed bio-slurry manure. Growth, yield and quality parameters were recorded and used to discern the treatment effects. Application of bio-slurry manure generally improved growth, yield and quality of carrots. Application of $7.8 \mathrm{t} / \mathrm{ha}$ of bio-slurry increased yields by $8.8 \%$ in season 1 and $23.5 \%$ in season 2 compared to the control. Leaf numbers, plant height, dry weights of shoot and roots and root volume were also generally higher for the $7.8 \mathrm{t} /$ ha treatment compared to other treatments. Total Soluble Solids of roots from plant treated with $7.8 \mathrm{t} /$ ha were higher by $12.7 \%$ in season 1 and $13.2 \%$ in season 2 compared to the control. The study recommends $7.8 \mathrm{t} /$ ha of bio-slurry manure for enhanced yield and quality of carrot.
\end{abstract}

Keywords: organic nutrient source, carrot performance, quality, brix content, biomass

\section{Introduction}

Carrot (Daucus carota L.) is an essential root vegetable commonly used in the diet of human beings. It is greatly treasured as food mostly because it is the best source of carotene; a precursor of Vitamin A (Zeb and Mahmood, 2004). Moreover, carrot contain also abundant quantities of nutrients and minerals (Handelman, 2001; Nicolle et al., 2004). Carrot roots are consumed uncooked in salads, steamed or boiled in vegetables and may also be prepared with other vegetables in the preparation of soups and stews (Anjum \& Amjad, 2002). Besides being food, carrot has therapeutic importance as it enhances resistance against blood and eye diseases (Pant \& Manandhar, 2007).

Carrot production can be a favourite enterprise for most small scale, resource poor farmers, since carrot is a short duration crop and higher yields can be obtained per unit area, hence profitable (Ahmad et al., 2005). In most developing countries, however, carrot yields per unit area still remain below the recommended world average. One of the reasons advanced for such low yields is low technological know how in production methods (Muendo \& Tschirley, 2004). In order to obtain high and quality yields of carrots good soil fertility and constant growth is required to facilitate the production and translocation of carbohydrates from leaves to roots.

The key limiting factors in crop growth, development and yield are the essential nutrients (nitrogen, phosphorous and potassium) and water (Glass, 2003; Parry et al., 2005). In most cases, carrot growers use synthetic fertilizers as the major supply of nutrients in order to attain higher yields and growth (Stewart et al., 2005; Dauda et al., 2008). The use of inorganic fertilizers has, however, been associated with human health problems and environment degradation (Arisha \& Bardisi, 1999). Moreover, the increasing costs of inorganic fertilizers have rendered them unaffordable to most resource-poor small scale growers.

Organic manure can serve as a substitute to mineral fertilizers. Manures supply the required nutrients, improve soil structure, increase microbial population and at the same time maintain the quality of crop produce (Wong et al., 1999; Nehra et al., 2001; Suresh et al., 2004; Dauda et al., 2008). Despite the large quantities of plant 
nutrients contained in inorganic fertilizers as compared to organic nutrients, the presence of growth promoting agents in organic fertilizers make them important for enhancement of soil fertility and productivity (Sanwal et al., 2007). Several authors have reported the importance of organic manure as a source of nutrients and a means of soil rejuvenation (Ghurman \& Sur, 2006; Adeleye et al., 2010).

Bio-slurry, the residual manure generated through anaerobic decomposition of various organic materials is considered a quality organic fertilizer (Islam, 2006). About 25 to $30 \%$ of organic matter is converted into biogas during the anaerobic fermentation process, while the rest becomes available as manure (bio-slurry). This residual manure is normally rich in macro and micro nutrients (Isam, 2006; Thu, 2007). Yield responses of vegetable crops to bio-slurry manure application have been reported in different crops including okra (Shahbaz, 2011) maize and cabbage (Karki, 2001). The use of decomposed bio-slurry manure in carrot production has not been tested in many carrot growing areas. This study is therefore aimed at investigating the potential use of decomposed bio-slurry manure to enhance carrot yield and quality.

\section{Materials and Methods}

\subsection{Study Site}

The study was conducted at Egerton University-Njoro in the Horticulture Research and Teaching Field. The farm is situated at a latitude of $0^{\circ} 23^{\prime}$ South, longitudes $35^{\circ} 35^{\prime}$ East in the Lower Highland III Agro Ecological Zone (Jaetzold \& Schmidt, 1983) and at an altitude of approximately 2,238 meters a.s.l. The soils are predominantly vitric mollic Andosols (Kinyanjui, 1979). During the study period, the site received $228.4 \mathrm{~mm}$ of rain during the first season (Oct 2010-Jan 2011) and 328.8mm during the second season (Feb to May 2011). Mean temperatures were $21.3^{\circ} \mathrm{C}$ in season 1 and $19.3^{\circ} \mathrm{C}$ in season 2 .

\subsection{Design and Treatment Application}

The experimental design was a Randomized Complete Block Design (RCBD) with three replications. Decomposed cattle and bio-slurry manure was applied at four levels $(0,2.6,5.2$ and $7.8 \mathrm{t} / \mathrm{ha})$. These rates were attained after putting into consideration the nitrogen requirement of carrots $(75 \mathrm{Kg} \mathrm{N} / \mathrm{ha})$, initial soil chemical analysis $(0.23 \% \mathrm{~N})$ and chemical composition of decomposed cow dung bio-slurry manure $(1.45 \% \mathrm{~N})$.

\subsection{Compost Manure Preparation}

Bio-slurry obtained from the biogas plant was decomposed using the passive aeration composting technique as described by Taiwo and Oso (2004). A plastic barrel measuring $2.5 \mathrm{~m}$ diameter and $3 \mathrm{~m}$ long with 9 holes perforated at intervals of $30 \mathrm{~cm}$ apart on the bottom sides was used for composting. Bio-slurry manure was moistened and placed into the plastic barrel and the ambient temperature was continuously monitored on weekly basis by inserting a thermometer into the composting plastic barrel until complete decomposition was attained when temperature stabilized.

\subsection{Soil, Manure and Plant Analysis}

For the initial soil characterization, the top $0-15 \mathrm{~cm}$ of the soil profile was sampled following a zigzag sampling design at various points across the entire experimental field using a soil auger after which a composite sample was derived for chemical analysis. At the end of each season, other soil samples were taken from each plot from within the top $0-15 \mathrm{~cm}$. The soil and manure samples were air dried, sieved and their nutrient composition analyzed. The soil $\mathrm{pH}$ was measured using a pH meter (Fisher Accument ${ }^{\circledR}$ ). Total nitrogen was determined following the Kjeldah method as described by Okalebo et al. (2002). Available potassium from soil and manure was determined by use of an Atomic Absorption Spectrophotometer (AAS) as described by Okalebo et al. (2002). Available $\mathrm{P}$ was determined calorimetrically using a Spectrophotometer (Novaspec ${ }^{\circledR}$ II). Soil analysis was conducted at the Egerton University and Kenya Agricultural Research Institute (KARI) Njoro Soil Analysis Laboratories.

\subsection{Land Preparation and Planting}

Land was ploughed to a depth of $30 \mathrm{~cm}$ and prepared into a fine tilth using rakes. Raised beds of $1.5 \mathrm{~m}$ by $1 \mathrm{~m}$ and $15 \mathrm{~cm}$ height were then prepared. Decomposed bio-slurry manure $(0,1.95,3.90$ and $5.85 \mathrm{~kg} / \mathrm{plot})$ was spread on each plot before being worked in/incorporated thoroughly into the soil. The soil was then moistened to field capacity and leveling done using a rake. Carrot seeds sourced from Kenya Seed Company suppliers, were then drilled to a depth of $1 \mathrm{~cm}$ in rows spaced at $20 \mathrm{~cm}$ apart. Thinning was done two weeks after emergence of the crop to attain the recommended spacing of $5 \mathrm{~cm}$ between plants (Sarkindiya \& Yakubu, 2006), giving a total of 78 plants per plot. 


\subsection{Routine Plant Maintenance Practices}

Cultural practices were applied uniformly to all the plots throughout the growing period. Water was applied on need basis to field capacity during the growing period. Continuous weeding by hand pulling was performed to ensure clean fields. Pests and diseases were controlled using recommended chemicals. Earthing up of carrot shoulders was done frequently to protect them from direct sunlight which could cause undesirable green colouration.

\subsection{Data Collection}

\subsubsection{Growth Parameters}

Height of five carrot plants from each treatment was measured using a ruler on a fortnight basis. The height measurement for each plant was taken from the ground level to the top of the shoot beginning from the time of final thinning. Obtained measurements were recorded in centimeters $(\mathrm{cm})$. On the same plants where stem length data were collected, the numbers of fully expanded leaves were also counted and readings were recorded as number of leaves per plant.

\subsubsection{Biomass Parameters}

Total biomass was determined after harvest using five plants which were randomly selected from each plot. The harvested plant shoots were detached from the roots and the shoots and roots separately oven dried at $70^{\circ} \mathrm{C}$ to constant weights. Thereafter, the roots and shoots were weighed using an electronic balance (CTG.1.2S, India Mart Inter Mesh limited) and readings recorded in grams per plant (g/plant).

\subsubsection{Yield Parameters}

Twenty carrot plants were randomly taken as a representative sample for determination of total fresh root weight per plot. Roots of the sampled plants were detached from the shoots and the fresh root weight determined using a weighing scale balance (NSR-Zhongshan Camry Electronic Limited). Obtained weights were recorded in kg/plot and later converted to ton/hectare. From the sample of 20 carrot roots, a sample of five carrots was randomly selected from each treatment for determination of the root volume using water displacement method and the volume recorded in $\mathrm{cm}^{3}$.

\subsubsection{Quality Parameters}

Quality parameters measured were root length, shoulder and core diameter and total soluble solids (\% brix). Upon harvest, 5 carrot roots were picked at random from the harvest of each plot. Root length was then determined using a ruler starting from the shoulder to the end of the root tips, and the mean root length computed. The shoulder and core diameter of roots were also measured at $0.5 \mathrm{~cm}$ from the top of the shoulder using a vernier caliper and a ruler, respectively and measurements recorded in centimeters $(\mathrm{cm})$. Total soluble solids were also measured using a hand-held refractometer (0-30\% Brix) from the same five carrot roots from each plot used to measure other quality parameters and readings recorded in percent.

\subsection{Data Analysis}

The data obtained were subjected to Analysis of Variance (ANOVA) using Proc GLM code of SAS (SAS Institute, 2002) and means for significant treatments separated using Turkey’s Honestly Significant Difference Test $(\mathrm{P} \leq 0.05)$.

\section{Results}

\subsection{Chemical Characteristics of the Soil and Bio-slurry Manure}

The soil at the site had a $\mathrm{pH}$ of 5.86 , total $\mathrm{N}$ of $0.23 \%$, available $\mathrm{P}$ of $0.16 \%$, exchangeable $\mathrm{K}$ of $0.10 \%$ and organic carbon of $1.73 \%$. Chemical composition of decomposed bio-slurry manure was $\mathrm{pH}$ of 8.42 , total $\mathrm{N}$ of $1.45 \%$, total $\mathrm{P}$ of $1.03 \%$, total $\mathrm{K}$ of $1.78 \%$ and organic carbon of $33.57 \%$.

\subsection{Growth Parameters}

A general trend of increase in all growth parameters with successive increase in level of bio-slurry manure application was observed during the study period (Figure 1). In both seasons, plant height was promoted most at the highest level ( $7.8 \mathrm{t} / \mathrm{ha}$ ) of bio-slurry application, recording a $15 \%$ increase compared to control treatment. Plants treated with intermediary levels of bio-slurry yielded taller plants than the control treatment although the difference was not significant in both seasons. Similar to plant height, more leaf numbers were recorded with application of bio-slurry manure compared to the control treatment. Plants treated with the highest level ( $7.8 \mathrm{t} / \mathrm{ha})$ of bio-slurry yielded $14.8 \%$ and $8.0 \%$ more leaves compared to control in season 1 and 2 , respectively. 

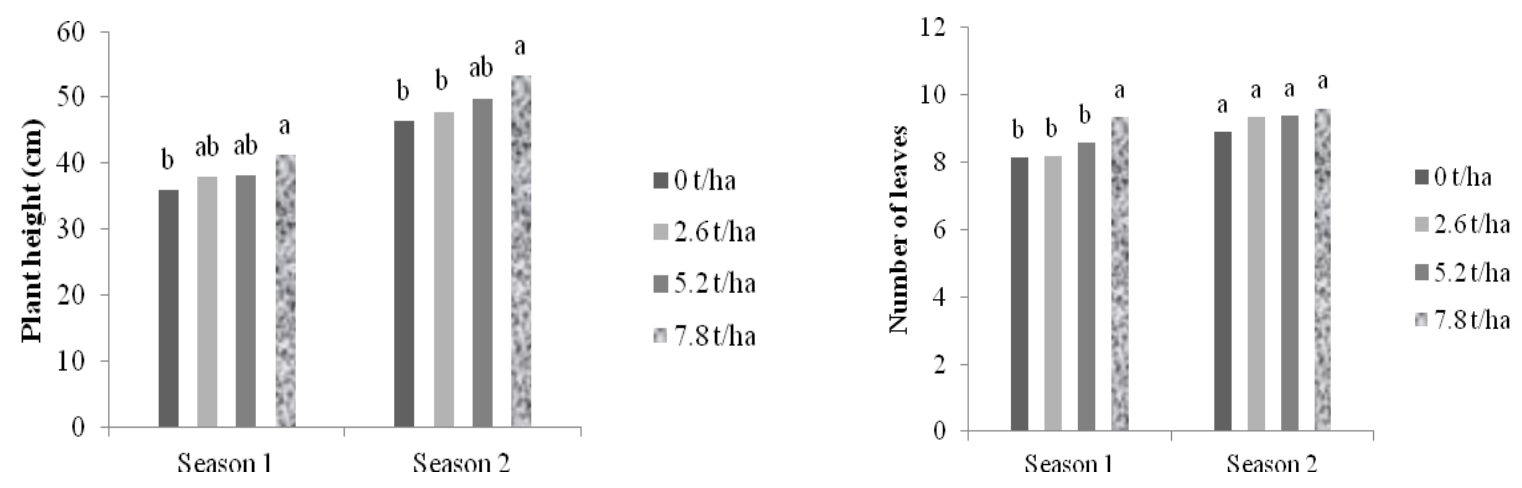

Figure 1. Effect of bio-slurry manure levels on plant height and leaf numbers of carrots

Application of bio-slurry manure influenced both carrot yield and yield components in two seasons (Table 1). Shoot dry biomass was higher for plants treated with bio-slurry manure compared to control plants, although the difference was significant only in season 2. Shoot dry biomass increased by $21.2 \%$ and $18.7 \%$ in season 1 and 2 , respectively following application of the highest level $(7.8 \mathrm{t} / \mathrm{ha})$ of bio-slurry compared to the control treatment. Similar effects were observed with root dry biomass where application of $7.8 \mathrm{t} / \mathrm{ha}$ of bio-slurry manure yielded the highest root dry biomass in both seasons. Root dry biomass under this treatment was $18.2 \%$ and $19.7 \%$ higher in season 1 and 2, respectively compared to the control treatment. Application of 7.8 t/ha bio-slurry manure also resulted in the highest root volume in both seasons; with $29.3 \%$ and $21 \%$ in season 1 and 2 , respectively compared to the control treatment. A general trend of increase in total fresh root yield with successive increase in bio-slurry manure application was also observed. Plants subjected to $7.8 \mathrm{t} /$ ha of bio-slurry manure treatment increased total yield by $23 \%$ compared to control plants in season 1 . In season 2 , treatment of plants with $5.2 \mathrm{t} / \mathrm{ha}$ and $7.8 \mathrm{t} /$ ha bio-slurry manure increased yield by $9.5 \%$, compared to the control. Plants treated with $2.6 \mathrm{t} / \mathrm{ha}$ and $5.2 \mathrm{t} /$ ha of bio-slurry also yielded more than control plants in season 1 . In season 2 , the difference in yield between $2.6 \mathrm{t} /$ ha bio-slurry treated and control plants was, however, not significant.

Table 1. Effect of bio-slurry manure levels on yield components and total fresh root weight of carrot

\begin{tabular}{lllll}
\hline $\begin{array}{l}\text { Bio-slurry } \\
(\mathrm{t} / \mathrm{ha})\end{array}$ & $\begin{array}{l}\text { Shoot dry } \\
\text { biomass } \\
(\mathrm{t} / \mathrm{ha})\end{array}$ & $\begin{array}{l}\text { Root dry } \\
\text { Biomass } \\
(\mathrm{t} / \mathrm{ha})\end{array}$ & $\begin{array}{l}\text { Root } \\
\text { volume } \\
\left(\mathrm{cm}^{3}\right)\end{array}$ & $\begin{array}{l}\text { Total } \\
\text { yield } \\
(\mathrm{t} / \mathrm{ha})\end{array}$ \\
\hline $\begin{array}{l}\text { Season 1 } \\
0.0\end{array}$ & $1.51 \mathrm{a}^{*}$ & $4.64 \mathrm{~b}$ & $60.20 \mathrm{~b}$ & $36.27 \mathrm{~d}$ \\
2.6 & $1.61 \mathrm{a}$ & $5.62 \mathrm{ab}$ & $66.83 \mathrm{ab}$ & $40.15 \mathrm{c}$ \\
5.2 & $1.72 \mathrm{a}$ & $5.63 \mathrm{ab}$ & $67.79 \mathrm{ab}$ & $42.26 \mathrm{ab}$ \\
7.8 & $1.83 \mathrm{a}$ & $5.67 \mathrm{a}$ & $77.88 \mathrm{a}$ & $44.78 \mathrm{a}$ \\
Season 2 & & & & $68.20 \mathrm{c}$ \\
0.0 & $3.05 \mathrm{~b}$ & $5.44 \mathrm{c}$ & $56.05 \mathrm{~b}$ \\
2.6 & $3.08 \mathrm{~b}$ & $5.60 \mathrm{bc}$ & $73.02 \mathrm{bc}$ & $57.79 \mathrm{ab}$ \\
5.2 & $3.38 \mathrm{ab}$ & $5.83 \mathrm{ab}$ & $76.83 \mathrm{ab}$ & $61.43 \mathrm{a}$ \\
7.8 & $3.62 \mathrm{a}$ & $6.51 \mathrm{a}$ & $82.57 \mathrm{a}$ & $61.39 \mathrm{a}$ \\
\hline
\end{tabular}

*Means within a column and a season followed by the same letter are not significantly different according to Tukey. Honestly Significantly Difference Test at $(P \leq 0.05)$.

\subsection{Quality Parameters}

Carrot quality parameters considered in this study were shoulder and core diameter, root length and total soluble 
solids. Except for core diameter in both seasons and shoulder diameter in season 2, all other quality attributes considered in this study were significantly improved following application of bio-slurry manure (Table 2). Carrot shoulder diameter was increased by $11.7 \%, 9.9 \%$ and $15 \%$ following application of $2.6 \mathrm{t} / \mathrm{ha}, 5.2 \mathrm{t} / \mathrm{ha}$ and $7.8 \mathrm{t} / \mathrm{ha}$ bio-slurry manure, respectively in season 1 . Although not significant, shoulder diameter increase ranged from $4 \%$ under $5.2 \mathrm{t} / \mathrm{ha}$ to $5.8 \%$ under $7.8 \mathrm{t} / \mathrm{ha}$ bio-slurry manure treatment, compared to control, in season 2 . The longest roots were obtained from plants treated with bio-slurry level $(7.8 \mathrm{t} / \mathrm{ha})$ while the shortest roots were recorded from the control plants in both seasons. Roots harvested from plants treated with $2.6 \mathrm{t} / \mathrm{ha}$ and $5.2 \mathrm{t} / \mathrm{ha}$ of bio-slurry manure also yielded longer roots than the control treatment although the difference was not significant in both seasons. A general increase in total soluble solids was also observed with increasing levels of bio-slurry manure. In season 1, total soluble solids were higher by $5.3 \%, 8.3 \%$ and $13.2 \%$ following application of $2.6 \mathrm{t} / \mathrm{ha}$, $5.2 \mathrm{t} / \mathrm{ha}$ and $7.8 \mathrm{t} / \mathrm{ha}$ bio-slurry manure, respectively compared to the control. A similar trend was established in season 2, where the highest increase in total soluble solids of $17.9 \%$ and least increase of $13.5 \%$ were recorded following application of $7.8 \mathrm{t} / \mathrm{ha}$ and $2.6 \mathrm{t} / \mathrm{ha}$ of bio-slurry manure, respectively than control.

Table 2. Selected carrot quality attributes as influenced by bio-slurry manure levels

\begin{tabular}{|c|c|c|c|c|}
\hline Bio-slurry (t/ha) & $\begin{array}{l}\text { Shoulder diameter } \\
(\mathrm{cm})\end{array}$ & Core diameter $(\mathrm{cm})$ & Root length $(\mathrm{cm})$ & $\begin{array}{l}\text { Total soluble solids } \\
(\%)\end{array}$ \\
\hline \multicolumn{5}{|l|}{ Season 1} \\
\hline 0.0 & $2.13 b^{*}$ & $1.08 \mathrm{a}$ & $15.47 \mathrm{~b}$ & $11.40 \mathrm{~b}$ \\
\hline 2.6 & $2.38 \mathrm{ab}$ & $1.13 \mathrm{a}$ & $18.8 \mathrm{ab}$ & $12.00 \mathrm{ab}$ \\
\hline 5.2 & $2.34 \mathrm{ab}$ & $1.15 \mathrm{a}$ & $18.8 \mathrm{ab}$ & $12.35 \mathrm{a}$ \\
\hline 7.8 & $2.45 \mathrm{a}$ & $1.12 \mathrm{a}$ & $19.1 \mathrm{a}$ & $12.90 \mathrm{a}$ \\
\hline \multicolumn{5}{|l|}{ Season 2} \\
\hline 0.0 & $2.77 \mathrm{a}$ & $1.38 \mathrm{a}$ & $19.76 b$ & $9.42 b$ \\
\hline 2.6 & $2.90 \mathrm{a}$ & $1.54 \mathrm{a}$ & $20.27 \mathrm{ab}$ & $10.69 \mathrm{ab}$ \\
\hline 5.2 & $2.88 \mathrm{a}$ & $1.45 \mathrm{a}$ & $20.55 \mathrm{ab}$ & $11.25 \mathrm{a}$ \\
\hline 7.8 & $2.93 \mathrm{a}$ & $1.55 \mathrm{a}$ & $20.85 \mathrm{a}$ & $11.11 \mathrm{a}$ \\
\hline
\end{tabular}

*Means within a column and a season followed by the same letter are not significantly different according to Tukey. Honestly Significantly Difference Test at $(P \leq 0.05)$.

\subsection{Selected Soil Nutrients Properties}

Table 3. Effect of bio-slurry manure levels on selected soil nutrients

\begin{tabular}{llll}
\hline Bio-slurry (t/ha) & Nitrogen (\%) & Phosphorous (\%) & Potassium (\%) \\
\hline Season 1 & & & \\
0.0 & $0.321 \mathrm{~b}^{*}$ & 0.0032 & 0.0137 \\
2.6 & $0.341 \mathrm{ab}$ & 0.0034 & 0.0137 \\
5.2 & $0.352 \mathrm{ab}$ & 0.0038 & 0.0138 \\
7.8 & $0.371 \mathrm{a}$ & 0.0048 & 0.0139 \\
Season 2 & & & \\
0.0 & $0.380 \mathrm{c}$ & 0.0036 & 0.0135 \\
2.6 & $0.391 \mathrm{bc}$ & 0.0037 & 0.0137 \\
5.2 & $0.412 \mathrm{~b}$ & 0.0038 & 0.0137 \\
7.8 & $0.522 \mathrm{a}$ & 0.0047 & 0.0139 \\
\hline
\end{tabular}

* Means within a column and a season followed by the same letter are not significantly different according to Tukey. Honestly Significantly Difference Test at $(P \leq 0.05)$. 
Application of bio-slurry manure at the different levels, significantly affected soil nitrogen but had no effect on soil phosphorous and potassium (Table 3). A general trend of increase in all the selected soil nutrients was observed with successive increase in bio-slurry manure application at the end of each growing season. Bio-slurry manure applied at the highest level of $7.8 \mathrm{t} / \mathrm{ha}$ increased residual nitrogen by $15.6 \%$ in season 1 and by $37.3 \%$ in season 2, respectively compared to control plots. Amounts of phosphorous and potassium retained in plots treated with the highest level $(7.8 \mathrm{t} / \mathrm{ha}$ ) of bio-slurry manure were also more by $5 \%$ and $1.4 \%$ in season 1 and by $30.5 \%$ and $3.0 \%$ in season 2 respectively, when compared to control plots.

\section{Discussion}

The role of organic manures in plant growth cannot be underscored. Organic manures have been shown to supply the required plant nutrients, improve soil structure and water holding capacity, increase microbial population and at the same time promote plant growth (Dauda et al., 2008). Findings of the current study support these arguments. An increase in all measured growth parameters was observed with successive increase in bio-slurry manure levels. Carrot plants treated with highest level (7.8 t/ha) of bio-slurry manure grew taller and had more number of leaves than control plants. The higher plant heights and leaf numbers obtained in the current study could be attributed to the ability of organic manure to supply the required plant nutrients and improve soil structure and water holding capacity, thereby promoting plant growth. Similar to the findings of this study, Mbatha (2008) also observed increased plant height and leaf numbers of carrots subjected to higher rates of different organic fertilizers (chicken, kraal and compost). Nitrogen, phosphorous and potassium are essential for good growth of plants. In the current study, higher plant heights and leaf numbers obtained could also be attributed to better levels of major nutrients $(\mathrm{N}, \mathrm{P}$, and $\mathrm{K}$ ) in the bio-slurry manure, as reflected by higher nutrient levels in the growing medium at the end of each growing season. Hailu et al. (2008) similarly observed higher plant height of carrots treated with organic $\mathrm{P}$ fertilizer (Orga) compared to control plants, which was attributed to the ability of phosphorus to enhance early plant growth.

Biomass and yield of carrot also tended to increase with every successive increase in bio-slurry manure level. Organic manures are known to have the ability to supply both macro and micro nutrients required for crop growth, development and final economic yield (Parry et al., 2005). Findings of our study support these arguments. N, P, K content of the soil were higher in bio-slurry treated plots at the end of each season, compared to the control plots. Carrot shoot and root biomass were also higher in bio-slurry treated plots, compared to the control. These findings could be attributed to improved nutrient availability and better soil structure that could have favoured shoot and root growth. Similar findings have been reported in turmeric plants subjected to chicken, goat and cow manure (Hossain \& Ishimine, 2007) and in amaranthus supplied with poultry manure (Maerere et al., 2001). Apart from increased nutrient supply, the higher root volume, fresh yield and dry biomass recorded for bio-slurry treated carrot could also be attributed to the effect of organic manures on soil conditions. According to Adeleye et al. (2010) organic manures provide more conducive soil conditions which enhance root expansion and development.

Quality improvement of vegetables and fruits has been observed as one of the beneficial effects of organic manures (Islam \& Momin, 2004). Longer roots and larger shoulder diameters recorded following application of bio-slurry manure in the current study attest to this. Carrot root length and shoulder diameter increased with increasing bio-slurry manure levels. On the other hand, core diameter was not affected by manure application, implying increasing quality with increasing bio-slurry level. Organic manures have been documented to increase soil water holding capacity and to reduce soil bulk density, hence, better root growth and expansion (Adeleye et al., 2010). Loose soil, following application of manures, may probably have favoured root growth and expansion leading to increased length and shoulder diameter of carrots. Increased root length has also been reported in amaranthus with increasing rates of poultry manure (Maerere et al., 2001) and in carrots with successive increase in different organic fertilizers (Mbatha, 2008). Bio-slurry manure at higher levels also enhanced total soluble solids of carrot roots. Enhanced total soluble solids following application of higher levels of bio-slurry manure observed in this study could be attributed to the better levels of macro-nutrients and micro-nutrients in manures required for growth and quality. Potassium is the key element in influencing quality of fruits and vegetables (Madge et al., 2003). Better potassium levels recorded in bio-slurry treated plots and carrot roots, could probably have contributed to enhanced total soluble solids. Results of the present study are in agreement with those by Ahmad et al (2005), who reported positive effect of farmyard manure on total soluble solids content of carrots and Aguyoh et al. (2010), who noted increased total soluble solids content of watermelon with increasing levels of tithonia manure. 


\section{Conclusion}

Amending soils with bio-slurry manure enhances the vegetative growth, fresh root yield and quality of carrots. Among the tested bio-slurry manure rates, the highest rate of $7.8 \mathrm{t} / \mathrm{ha}$ proved to be the best in enhancing the vegetative growth, fresh root yield and quality of carrots.

\section{Recommendation}

The present findings of these study recommends use of $7.8 \mathrm{t} / \mathrm{ha}$ of bio-slurry manure for improved yield and quality of carrots. More research testing different rates under different soil and agro ecological zone conditions may be beneficial in coming up with specific rates suitable rates for the different production area.

\section{Acknowledgement}

The authors are grateful to, Egerton University, Njoro Campus and the Department of Crops Horticulture and Soils for providing the necessary support.

\section{References}

Aguyoh, J. N., Audi, W., Saidi, M., \& Gao, Q. L. (2010). Growth, yield and quality response of watermelon (Citrullus lanatus CV. Crimson Sweet) subjected to different levels of tithonia manure. International Journal of Science and Nature, 1(1), 7-11.

Adeleye, E. O., Ayeni, L. S., \& Ojeniyi, S. O. (2010). Effect of poultry manure on soil Physico-Chemical properties, leaf nutrients content and yield of yam (Discorea rotundata) on Alfisol in South Western Nigeria. Journal of American Science, 6(10), 871-878.

Ahmad, B., Hassan, S., \& Bakhsh, K. (2005). Factors Affecting Yield and Profitability of Carrot in Two Districts of Punjab. International Journal of Agriculture and Biology, 7(5), 794-798.

Ahmad, Z., Ali, N., Ahmad, M., Ulhag, S., \& Ahmad, S. (2005). Yield and economics of carrot production in organic farming. Sarhad Journal of Agriculture, 21(3), 357-364.

Amjad, M., Naz, S., \& Ali, S. (2005). Growth and seed yield of carrot as influenced by different regimes of nitrogen and potassium. Journal of Research Science, 16(2), 73-78.

Anjum, M. A., \& Amjad, M. (2002). Influence of mother root size and plant spacing on carrot seed production. Journal of Resource Science, 13(2), 105-112.

Arisha, H. M., \& Bardisi, A. (1999). Effect of mineral fertilizers and organic fertilizers on growth, yield and quality of potato under sandy soil conditions. Journal of Agricultural Resource, 26, 391-405.

Dauda, S. N., Ajayi, F. A., \& Ndor, E. (2008). Growth and yield of water melon (Citrullus lanatus) as affected by poultry manure application. Journal of Agriculture and Social Science, 4, 121-124.

Food and Agriculture Organization. (2008). FAO statistics. www.fao.org.

Ghuman, B. S., \& Sur, H. S. (2006). Effect of manuring on soil properties and yield of rain fed wheat. Journal of Indian Society of Soil Science, 54(1), 6-11.

Glass, A. D. M. (2003). Nitrogen use efficiency of crop plants: physiological constraints upon nitrogen absorption. Crit. Rev. Plant Science, 22, 453-470. http://dx.doi.org/10.1080/07352680390243512

Gurung, J. B. (1997). Review of Literature on Effect of Slurry Use on Crop Production. Biogas Support Programme. p. 102 BSP Lib Temp No. 20.

Hailu, S., Seyoum, T., \& Dechassa, N. (2008a). Effect of combined application of organic P and inorganic N fertilizers on yield of carrot. African Journal of Biotechnology, 7(1), 27-34.

Handelman, G. J. (2001). The evolving role of carotenoids in human biochemistry. Nutrition, 17, 818-822. http://dx.doi.org/10.1016/S0899-9007(01)00640-2

Hardy, S., \& Sanderson, G. (2010). Citrus maturity testing. Prime Facts 980.

Hossain, A., \& Ishimine, Y. (2007). Effects of Farmyard Manure on Growth and Yield of Turmeric (Curcuma longa L.) Cultivated in Dark-Red Soil, Red Soil and Gray Soil in Okinawa, Japan. Plant production science, 10(1), 146-150. http://dx.doi.org/10.1626/pps.10.146

Islam, M. S., \& Momin, L. (2004). Organic Farming in Bangladesh: Recent Development at BARI and Future Needs, Gazipur, Bangladesh.

Islam, S. (2006). Use of Bio-slurry as Organic Fertilizer in Bangladesh Agriculture. Prepared for International 
Workshop on the use Bio-slurry for Domestic Biogas Programmes $27^{\text {th }}-28^{\text {th }}$ September, Bangkok, Thailand.

Jaetzold, R., \& Schmidt, H. (1983). Farm Management Handbook of Kenya. Vol. II Natural Conditions and Farm Management Information. Part B. Central Kenya (Rift Valley and Central Province). Ministry of Agriculture. pp. 389-413. Nairobi, Kenya.

Karki, K. B. (2001). Response to bio-slurry Application on Maize and cabbage in Laliptur District. Final Field Research Report Submitted to Alternative Energy Promotion Centre of Ministry of Science and Technology. October, 2001. Pulchok .Nepal.

Karkleliene, R. Danguole, J., \& Viskelis, P. (2007). Productivity and Quality of Carrot (Daucus sativus rohl.) and onion (Allium cepa 1.) cultivars and hybrids. Journal of Horticulture Science, 26(3).

Kinyanjui, H. C. (1979). Detailed soil survey of Tatton Farm, Egerton College, Njoro. Ministry of Agriculture-National Agricultural Laboratories. Nairobi, Kenya.

Madge, D., Jaeger, C., \& Clarke, S. (2003). Organic farming: Carrot production and marketing. State of Victoria, Department of Primary Industries.

Maerere, A. P., Kimbi, G. G., \& Nonga, D. L. M. (2001). Comparative effectiveness of animal manures on soil chemical properties, yield and root growth of amaranthus. African Journal of Science and Technology, 1(4), $14-21$.

Mandal, U. K., Singh, G., Victor, U. S., \& Sharma, K. L. (2003). Green manuring: Its effect on soil properties and crop growth under rice-wheat cropping system. European Journal of Agronomy, 19, 222-237. http://dx.doi.org/10.1016/S1161-0301(02)00037-0

Mbatha, A. N. (2008). Influence of organic fertilizers on the yield and quality of cabbage and Carrots. Msc.Thesis, University of the Free State Bloemfontein.

Muendo, K. M., \& Tschirley, D. (2004). Improving Kenya's Domestic Horticultural Production and Marketing System: Current competitiveness, forces of change, and challenges for the future. Working paper No. 08A Tegemeo Institute of Agricultural Policy and Development. Egerton University, Kenya.

Nehra, A. S., Hooda, I. S., \& Singh, K. P. (2001). Effect of integrated nutrient management on growth and yield of wheat (Triticurn aestivum L.). Indian Journal of Agronomy, 45, 112-17.

Nicolle, C., Simon, G., Rock, E., Amouroux, P., \& Remesy, C. (2004). Genetic variability influences carotenoids, vitamin, phenolic and mineral content in white, yellow, purple, orange and dark orange cultivars. Journal of American Society Horticulture Science, 129(4), 523-529.

Okalebo, J. R., Gathua, K. W., \& Woomer, P. L. (2002). Laboratory Methods of Soil and Plant Analysis: A Working Manual. (2nd ed.). TSBF-CIAT and Sacred Africa, Nairobi.

Parry, M. A. J., Flexas, J., \& Medrano, H. (2005). Prospects for crop production under drought: research priorities and future directions. Annual Applied Biology, 147, 211-226. http://dx.doi.org/10.1111/j.1744-7348.2005.00032.x

Razzak, A. (2006). Production status of organic manure in Bangladesh. Bangladesh Livestock Research Institute's Report, Dhaka, Bangladesh.

SAS Institute. (2002). SAS Release 9. SAS Institute, Cary.

Salminen, E., Rintala, J., Harkonen, J., Kuitunen, M., Hogmander, H., \& Oikari, A. (2001). Anaerobically digested poultry slaughterhouse wastes as fertilizer in agriculture. Bioresource technology, 78(1), 81-88. http://dx.doi.org/10.1016/S0960-8524(00)00160-7

Shahabz, M. (2011). Potential of bio-slurry and compost at different levels of inorganic nitrogen to improve growth and yield of okra (Hibiscus esculetus L.). Msc.Thesis, University of Agriculture Faisalabad, Pakistan.

Sanwal, S. K., Lakminarayana, K., Yadav, R. K., Rai, N., Yadav, D. S., \& Mousumi, B. (2007). Effect of organic manures on soil fertility, growth, physiology, yield and quality of turmeric. Indian Journal of Horticulture, 64(4), 444-449.

Sarkindiya, S., \& Yakubu, A. I. (2006). Effect of intra row spacing, fertilizer Level and weeding on the performance of carrot. Faculty of Agriculture, Bayero University.

Stewart, M. W., Dibb, W. D., Johnston, E. A., \& Smyth, J. T. (2005). The Contribution of Commercial Fertilizer Nutrients to Food Production. Agronomy Journal, 97, 1-6. http://dx.doi.org/10.2134/agronj2005.0001 
Suresh, K. D., Sneh, G., Krishna, K. K., \& Mool, C. M. (2004). Microbial biomass carbon and microbial activities of soils receiving chemical fertilizers and organic amendments. Archives Agronomy Soil Scienc, $50,7-641$.

Swift, M. J., Woomer, P. L. (1993). Organic matter and the sustainability of agricultural System: Definition and measurement In: K. Mulongoy and R. Merckx (Eds.) Soil Organic Matter Dynamics and Sustainability of Tropical Agriculture, 3-18.

Taiwo, L. B., \& Oso, B. A. (2004). Influence of composting techniques on microbial succession, temperature and $\mathrm{pH}$ in a composting municipal solid waste. African Journal of Biotechnology, 3(4), 239-243.

Thu, L. T. X. (2006). Bio-slurry Utilization in Vietnam. Half Year Country Report.

Wong, J. W. C., Ma, K. K., Fang, K. M., \& Cheung, C. (1999). Utilization of manure compost for organic farming in Hong Kong. Bio-resource Technology, 67, 6-43. http://dx.doi.org/10.1016/S0960-8524(99)00066-8

Zeb, A., \& Mahmood, S. (2004). Carotenoids contents from various sources and their potential health applications. Pakistan Journal of Nutrition, 3(3), 199-204. http://dx.doi.org/10.3923/pjn.2004.199.204 